University of Nebraska - Lincoln

DigitalCommons@University of Nebraska - Lincoln

Publications from USDA-ARS / UNL Faculty

U.S. Department of Agriculture: Agricultural

Research Service, Lincoln, Nebraska

2009

Comparative Metabolism of Benzo(a)pyrene by Ovarian

Microsomes of Various Species

\author{
Deacqunita L. Harris \\ Meharry Medical College \\ Ashley C. Huderson \\ Meharry Medical College \\ Mohammad S. Niaz \\ Meharry Medical College \\ J. Joe Ford \\ U. S. Meat Animal Research Center \\ Anthony E. Archibong \\ Meharry Medical College \\ See next page for additional authors
}

Follow this and additional works at: https://digitalcommons.unl.edu/usdaarsfacpub

Part of the Agricultural Science Commons

Harris, Deacqunita L.; Huderson, Ashley C.; Niaz, Mohammad S.; Ford, J. Joe; Archibong, Anthony E.; and Ramesh, Aramandla, "Comparative Metabolism of Benzo(a)pyrene by Ovarian Microsomes of Various Species" (2009). Publications from USDA-ARS / UNL Faculty. 414.

https://digitalcommons.unl.edu/usdaarsfacpub/414

This Article is brought to you for free and open access by the U.S. Department of Agriculture: Agricultural Research Service, Lincoln, Nebraska at DigitalCommons@University of Nebraska - Lincoln. It has been accepted for inclusion in Publications from USDA-ARS / UNL Faculty by an authorized administrator of DigitalCommons@University of Nebraska - Lincoln. 


\section{Authors}

Deacqunita L. Harris, Ashley C. Huderson, Mohammad S. Niaz, J. Joe Ford, Anthony E. Archibong, and Aramandla Ramesh 


\title{
Comparative Metabolism of Benzo(a)pyrene by Ovarian Microsomes of Various Species
}

\author{
Deacqunita L. Harris, ${ }^{1}$ Ashley C. Huderson, ${ }^{1}$ Mohammad S. Niaz, ${ }^{2}$ J. Joe Ford, ${ }^{3}$ \\ Anthony E. Archibong, ${ }^{2}$ Aramandla Ramesh ${ }^{1}$ \\ ${ }^{1}$ Department of Cancer Biology, Meharry Medical College, Nashville, Tennessee 37208, USA \\ ${ }^{2}$ Department of Obstetrics and Gynecology, Meharry Medical College, Nashville, \\ Tennessee 37208, USA \\ ${ }^{3}$ USDA-ARS, U. S. Meat Animal Research Center, Clay Center, Nebraska 68933, USA
}

Received 14 August 2008; revised 6 October 2008; accepted 19 October 2008

\begin{abstract}
Knowledge of the ability of the female reproductive system to metabolize polycyclic aromatic hydrocarbons (PAHs) is critical to the diagnosis and management of female infertility and for risk assessment purposes. The PAHs are a family of widespread pollutants that are released into the environment from automobile exhausts, cigarette smoke, burning of refuse, industrial emissions, and hazardous waste sites. In exposed animals, PAHs become activated to reactive metabolites that interfere with target organ function and as a consequence cause toxicity. The extent of susceptibility to PAH exposure may depend on the ability of animals to metabolize these chemicals. The present study has been undertaken to assess whether any differences exist among mammals in the metabolism of benzo(a)pyrene (BaP), a prototypical $\mathrm{PAH}$ compound. Microsomes isolated from the liver and ovaries of rats, mice, goats, sheep, pigs, and cows were incubated with $5 \mu \mathrm{M}$ BaP. Postincubation, samples were extracted with ethyl acetate and analyzed for BaP/metabolites by reverse-phase HPLC with fluorescence detection. The rate of metabolism (pmol of metabolite/min/mg protein) was found to be more in liver than in ovary in all the species studied $(P<0.05)$. The differences in metabolite concentrations were statistically significant $(P<0.0001)$ among the various species in both organs studied. Multiple species comparison also revealed that the differences were statistically significant $(P<0.001)$ between rodents (rat and mouse) and higher mammals (ewe, sow, and cow). Even among the higher mammals, in a majority of the cases, the differences in metabolite concentrations were significantly different $(P<0.001)$ both in ovary and liver. The BaP metabolites identified were 4,5-diol; 7,8-diol; 9,10-diol; 3-hydroxy BaP; and 9-hydroxy BaP. The rodent microsomes produced considerably higher proportion of BaP 4,5-diol and 9,10-diol than did cow, sow, goat, and sheep. However, microsomes from higher mammals converted a greater proportion of BaP to 3-hydroxy and 9-hydroxy $\mathrm{BaP}$, the detoxification products of BaP. Overall, our results revealed a great variation among species to metabolize BaP. (c) 2008 Wiley Periodicals, Inc. Environ Toxicol 24: 603-609, 2009.
\end{abstract}

Keywords: benzo(a)pyrene; polycyclic aromatic hydrocarbons; ovarian microsomes; liver microsomes; metabolism; HPLC

Correspondence to: A. Ramesh; e-mail: aramesh@mmc.edu

Contract grant sponsor: National Institutes of Health (NIH).

Contract grant numbers: G12 RR03032, 1S11ES014156-01A1-Project\#3, 5T32HL007735-12, 1U54HD044315.

Published online 2 December 2008 in Wiley InterScience (www. interscience.wiley.com). DOI 10.1002/tox.20461

\section{INTRODUCTION}

In recent years, environmental toxicants have been implicated in various reproductive disorders in humans (Younglai et al., 2007). The difficulties encountered in studying the mechanism of action of environmental chemicals on human reproduction necessitate employing 
laboratory animals and animal models for mechanistic reproductive studies (WHO, 2001). Therefore, understanding the mechanism by which environmental toxicants are metabolized in the female reproductive system of animals will be of importance in the diagnosis and management of female fertility issues. Additionally, in reference to environmental health issues, chemical-specific metabolism data will aid in the generation of a compendium of interspecies default factors used for risk assessment (Walton et al., 2001).

Some of the environmental chemicals act as reproductive toxicants in that they bind to the receptors necessary for the regulation of reproductive organs, thus contributing to impairment in sexual behavior, gamete function, and delivery of the new born. One such environmental chemical that has been categorized as a reproductive toxicant is benzo(a)pyrene (BaP; Charles et al., 2000; Archibong et al., 2002; Inyang et al., 2003; Ramesh et al., 2008). Automobile exhausts, cigarette smoke, biomass burning, charcoalbroiled meat, industrial emissions, municipal incinerators, and hazardous waste sites contribute considerable amounts of this chemical (IPCS, 1998) to human exposure. In exposed animals and humans, BaP becomes activated in organs particularly the ovaries, to reactive metabolites that interfere with the latter organ function (reviewed in Ramesh et al., 2004) and as a consequence cause ovarian failure.

The rationale for conducting this study was to assess the qualitative and quantitative differences among different mammalian species in ovarian and hepatic microsomal metabolism of $\mathrm{BaP}$, a prototypical polycyclic aromatic hydrocarbon (PAH) compound. Association has been established between the substantially higher levels of PAH exposures with increased incidence of female reproductive toxicity in laboratory animals (Borman et al., 2000; Jurisicova et al., 2007; Tsai-Turton et al., 2007) and humans (Matikainen et al., 2001; Neal et al., 2007). Therefore, information on the ability of these mammals to metabolize $\mathrm{BaP}$ will be useful for assessing risks to humans arising from different sources of exposure to this PAH (occupational, environmental exposures, and consumption of contaminated meats).

\section{MATERIALS AND METHODS}

\section{Test Species/Tissue Samples}

Microsomes were isolated from the liver and ovarian tissues of the following animals: rat (age $=10$ weeks), mouse (age $=10$ weeks), sheep (age $=20-30$ months), goat (age $=16-24$ months), pig (age $=9$ months), and cow (age $=$ 36 months).

Pig ovary and liver samples were obtained from the USDA Meat Animal Research Center, Clay Center, NE; cow, sheep, and goat ovary and liver samples were obtained from abattoirs in and around Nashville, TN. Similar organ samples from rat and mouse were obtained from animals maintained in-house. All animals used in this study were mature and healthy and were not subjected to any form of treatment/medication. Except for tissue samples collected from the abattoirs, the rest of the tissues used in this study were collected from animals whose uses for experiments were approved by the respective Institutional Animal Care and Use Committees.

\section{Preparation of Microsomes}

Ovary and liver samples from autopsied animals (rat and mouse), and animals from the USDA facility and abattoirs after sacrifice and evisceration (cow, sheep, goat, and pig) were immediately frozen on dry ice and stored at $-70^{\circ} \mathrm{C}$ until isolation of microsomes. Microsomal fraction preparation and analysis were conducted simultaneously on tissues from representative species mentioned above, in order to minimize procedural variations. A minimum of five samples/organ/species were used for analysis.

Microsomal fractions were prepared, and processed as described by Schenkman and Jansson (1999) with some modifications. The connective tissues surrounding the ovary and fat on liver samples were removed following which, they were washed in chilled $\left(4^{\circ} \mathrm{C}\right)$ isotonic saline to remove excess blood. Each ovary and liver samples were individually cut into small pieces using sterile scalpel blades, minced separately with a fine pair of scissors and thoroughly mixed to obtain a homogenous mixture of minced tissue samples per animal. One gram of each minced sample was chilled in isotonic saline for 5 min prior to being homogenized in two volumes of sucrose-TKM buffer (sucrose $0.25 \mathrm{M}$, Tris $80 \mathrm{mM}, \mathrm{KCl} 25 \mathrm{mM}, \mathrm{MgCl}_{2} 5$ $\mathrm{mM}, \mathrm{pH}$ 7.4). Each minced tissue sample homogenate was centrifuged at $10000 \times g$ for $10 \mathrm{~min}$, supernatant harvested and subjected to a second centrifugation at $15000 \times g$ for 15 min to pellet down nuclei and mitochondria. Each resultant supernatant was centrifuged at $100000 \times g$ for $60 \mathrm{~min}$ at $4{ }^{\circ} \mathrm{C}$ following which, the cytosolic supernatant and microsomal pellet were separated. Each microsomal pellet was rinsed twice with $5 \mathrm{~mL}$ of sucrose-TKM buffer and resuspended in $5 \mathrm{~mL}$ of the same buffer. Ovarian or liver microsomes were aliquoted into cryovials (Wheaton Science Products, Millville, NJ), and stored frozen at $-80^{\circ} \mathrm{C}$ until used for studying BaP metabolism. Protein content of each microsomal preparation was determined according to the method of Bradford (1976).

\section{Microsomal Incubations and Metabolism Studies}

Pilot studies were conducted to establish optimal conditions for microsomal protein concentration, substrate 
concentration, and time of incubation of reaction mixtures in the assay. The results (data not shown here) showed that reaction rates were consistent with linearity of metabolism occurring in the first $15 \mathrm{~min}$, at microsomal protein and substrate concentrations of $0.5 \mathrm{mg} / \mathrm{mL}$ and $5 \mu \mathrm{M}$, respectively.

Before conducting metabolism studies, microsomes were thawed at room temperature and $120 \mu \mathrm{L}$ of the microsomal pellet resuspended in TKM buffer (final protein concentration $=0.5 \mathrm{mg} / \mathrm{mL}$ ) were added to $5 \mathrm{~mL}$ of cocktail containing NADPH (0.72 mM), EDTA (100 mM), KPO4 (100 mM), $\mathrm{MgCl}_{2} \cdot 6 \mathrm{H}_{2} \mathrm{O}(3.75 \mathrm{mM})$. Samples per animal were preincubated for $2 \mathrm{~min}$ at $37^{\circ} \mathrm{C}$ in a tissue shaker (Precision Scientific Instruments, Chicago, IL) prior to being distributed to a treatment and a control reaction tubes in a 2 $\times 3 \times 7$ factorial arrangement (two organs, three classes of treatment, and seven species). Treatment consisted of exposure in vitro to $5 \mu \mathrm{M}$ BaP (CAS No. 50-32-8; $98 \%$ pure, Sigma Chemical Co., St. Louis, MO) dissolved in dimethyl sulfoxide. After $15 \mathrm{~min}$ incubation at $37^{\circ} \mathrm{C}$, the reaction was stopped with $8 \mathrm{~mL}$ of ethyl acetate containing butylated hydroxytoluene $(0.2 \mathrm{mg} / \mathrm{mL})$. Benzo(a)pyrene metabolites were extracted twice with ethyl acetate. The organic layer was removed and evaporated under nitrogen. Each sample residue was dissolved in $500 \mu \mathrm{L}$ methanol, passed through Acrodisc filters $(0.45 \mu \mathrm{m} ; 25 \mathrm{~mm}$ diameter, Gelman Sciences, Ann Arbor, MI), and subjected to reversephase HPLC for analyses of BaP metabolites as described previously (Ramesh et al., 2001). Benzo(a)pyrene metabolite standards were obtained from the National Cancer Institute Chemical Carcinogen Repository (Midwest Research Institute, Kansas City, MO). Though this analytical method was set-up originally for the rat, it was optimized for other species analyzed in our laboratory (Walker et al., 2006). Controls were processed in parallel with experimental samples under identical assay conditions. Dimethyl sulfoxide (vehicle for $\mathrm{BaP}$ ) was used as a negative control while reaction mixtures without $\mathrm{BaP}$ or microsomes served as positive controls. All incubations were performed in triplicate for each ovarian and hepatic microsomal sample. The variability among triplicates was less than $10 \%$. The rates of $\mathrm{BaP}$ metabolism (formation of BaP metabolites) were expressed as pmol of product formed per min per $\mathrm{mg}$ of microsomal protein. Because $\mathrm{BaP}$ and its metabolites are suspected carcinogens, they were handled in accordance with NIH guidelines for preventing exposure of laboratory personnel to this chemical (NIH, 1981).

\section{Effect of Estrous Cycle on BaP Metabolism}

To delineate the influence of different phases of estrous cycle on BaP metabolism, ovaries from commercial crossbred prepubertal gilts (7-8 month old; ovaries with follicles and no corpora lutea) and those of postpubertal gilts (ova- ries with corpora lutea of various stages of development or corpora albicantia) were used.

\section{Statistics}

Data on microsomal mean BaP metabolite concentrations were analyzed by ANOVA with repeated measures and the differences among means were tested for significance by orthogonal contrasts (Steel and Torrie, 1980).

\section{RESULTS AND DISCUSSION}

The concentration of $\mathrm{BaP}(5 \mu \mathrm{M})$ used in the present study is higher than the actual concentrations $(0.025-0.086 \mathrm{ng} / \mathrm{g}$ wet tissue) reported in the liver, lung, and breast of healthy humans and smokers (Beach et al., 2000; Goldman et al., 2001). Nonetheless, this concentration was chosen because of its relevance to environmental levels of $\mathrm{BaP}$ in hazardous waste sites, former industrial sites, and exposure concentrations for "at risk" populations such as smokers and occupationally exposed individuals (IPCS, 1998; Ramesh et al., 2004).

Before incubation of microsomes with $\mathrm{BaP}$, ovarian tissue homogenates were analyzed for the presence of $\mathrm{BaP}$ parent compound or its metabolites to ensure their absence in as much as they (BaP and its metabolites) could be imposed by diet on organs of farm animals in particular. Subsequent to incubation of microsomes with $\mathrm{BaP}$, no unmetabolized $\mathrm{BaP}$ (parent compound) was detected. Regardless of species, ovary and liver microsomes exhibited the capability to metabolize BaP based on detected levels of metabolites, which were absent in the control reaction mixtures $(P<0.005)$. The concentrations of BaP metabolites produced by the ovarian microsomes varied among the species. The in vitro metabolism of $\mathrm{BaP}$ was highest in the cow and lowest in the mouse $($ cow $>$ pig $>$ goat $>$ sheep $>$ rat $>$ mouse; treatment $\times$ species interaction, $P<$ 0.005). Compared to rodents, the BaP metabolite concentrations produced by porcine, ovine, and bovine ovarian microsomes were higher $(P<0.05$; Fig. 1$)$. The total $\mathrm{BaP}$ metabolite concentration profiles of hepatic microsomes for the above mentioned species were similar to those of their respective ovaries. The overall metabolite concentrations in liver were species-dependent and rodents had the least concentration of BaP metabolites $(P<0.05$; treatment $\times$ organ $\times$ species) compared with the other species. Substantial differences in ovarian and liver microsomal metabolism of $\mathrm{BaP}$ exist among the various species tested. Results of cross-species comparison of metabolite concentrations are shown in Figure 2. Data reported in Figure 1 was subjected to individual species-wise comparison, which showed that the differences in metabolite concentrations were statistically significant $(P<0.0001)$ in the two organs studied. 

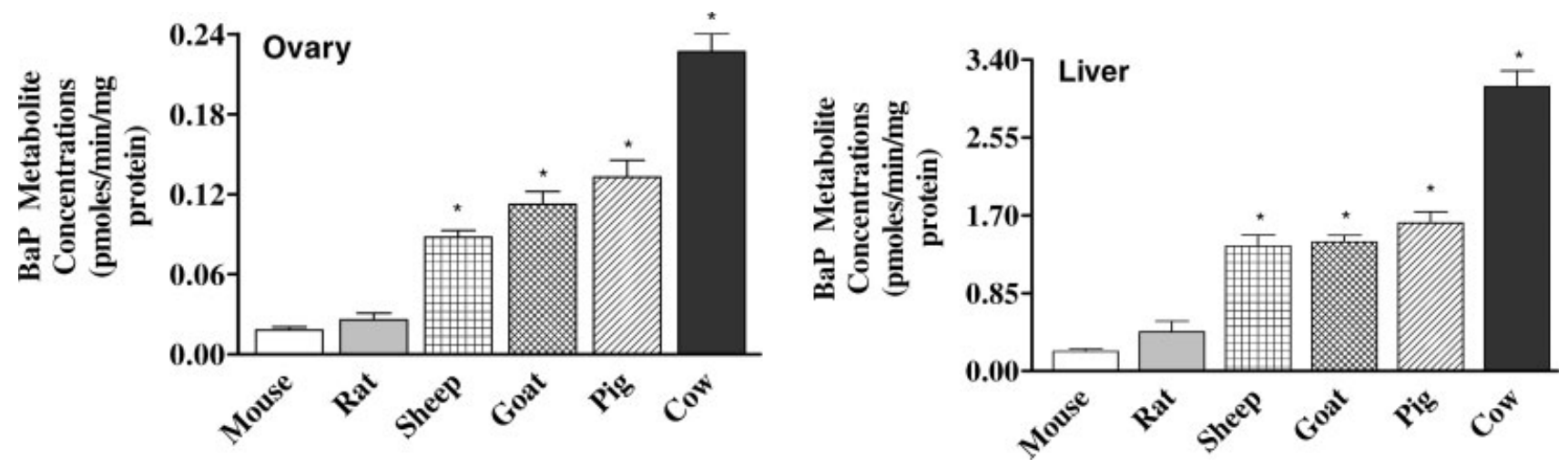

Fig. 1. Comparison of the metabolism of benzo(a)pyrene in ovarian and hepatic microsomes of rat, mouse, sheep, goat, pig, and cow. Values are expressed as mean concentration of total metabolites + SE ( $n=5$ for each species). Data from triplicate determination (variability was $<10 \%$ ) of five individual animals from each species were compared. Asterisks denote statistical significance $(P<0.05)$ in $\mathrm{BaP}$ metabolite concentrations between rat and the rest of the animal species.

Multiple species comparison of this data, performed by two-way ANOVA also revealed that the differences were statistically significant $(P<0.001)$ between rodents (rat and mouse) and higher mammals (ram, pig, and cow). Additionally, even among the higher mammals, in a majority of the cases, the differences in metabolite concentrations were different $(P<0.001)$ both in ovary and liver (Fig. 1$)$. Interestingly, hepatic microsomes produced the greatest quantities of metabolites relative to that of ovarian microsomes in all the species studied $(P<0.05$; Fig. 1$)$. This observation is not surprising in as much as the liver functions as the main detoxifying organ in mammals (Wall et al., 1991). The variation in production of $\mathrm{BaP}$ metabolites by microsomes in animal groups used in this study could be attributed to differences in constitutive levels of drug metabolizing enzymes (Lewis et al., 1998). Also, induction of microsomal enzymes by dietary ingredients (Ioannides, 1999) especially in farm animals cannot be ruled out.
Since it is established that metabolism of PAHs in mammalian ovary is hormonally regulated (Bengtsson et al., 1987), we measured the BaP metabolite concentrations produced by microsomes isolated from prepubertal and cycling pigs and established that $\mathrm{BaP}$ metabolism was indeed influenced by stage of the sexual development. Microsomes isolated from gilts that were at mid-luteal and follicular phases metabolized BaP rapidly, compared to those in the prepubertal stage (Table I). Normally, one would expect to see increased concentrations of $\mathrm{BaP}$ metabolites in the ovaries of cycling than prepubertal pigs because the cycling animals secrete more ovarian steroids (estrogen and progesterone) by antral follicles of different stages of maturation and the corpora lutea (CL) (Archibong, 1987). On the contrary, the high concentrations of metabolites in luteal phase are not uncommon due to a high constitutive expression of CYP-regulated luteal estrogen. Our findings are in agreement with those of Eliasson et al. (1997) who reported that
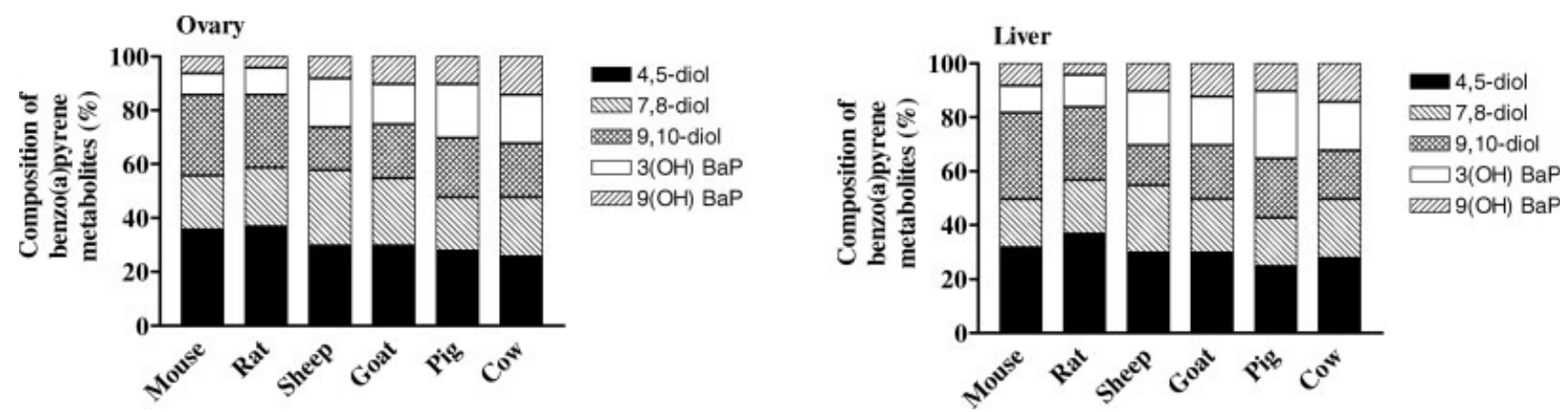

Fig. 2. Metabolite profiles of benzo(a)pyrene in ovary and liver microsomes of rat, mouse, sheep, goat, pig, and cow. Values are expressed as the percentage of individual metabolite types among the total metabolites (sum of individual concentrations of BaP 9,10-diol; BaP 4,5-diol; BaP 7,8-diol; 1-hydroxy, 3-hydroxy, and 9-hydroxy BaP) formed; $n=5$ for each species. 
TABLE I. Benzo(a)pyrene metabolite concentrations generated by microsomes from various stages of estrous cycle in pig

\begin{tabular}{llc}
\hline Ovarian Status & \multicolumn{1}{c}{ Description } & $\begin{array}{c}\text { BaP Metabolite Concentrations } \\
\text { (pmoles/min/mg protein) }\end{array}$ \\
\hline Prepubertal $(n=6)$ & Minimal estrogen stimulation of the uterus & $0.10 \pm 0.0001^{* * * * *}$ \\
Prepubertal $(n=4)$ & Some uterine stimulation & $0.12 \pm 0.01^{* * *}$ \\
Postpubertal $(n=2)$ & Follicular to late follicular phases, 14-15CA, many 4-5 mm follicles & $0.17 \pm 0.02^{* *}$ \\
Postpubertal $(n=5)$ & Mid-luteal, 11-17 CL & $0.22 \pm 0.02$ \\
\hline
\end{tabular}

CA, corpora albicans; CL, corpus luteum.

${ }^{* * * * *} P<0.0001$; prepubertal (minimal estrogen stimulation) versus postpubertal (follicular and mid-luteal).

${ }^{* * * *} P<0.001$; prepubertal (some estrogen stimulation) versus postpubertal (follicular and mid-luteal).

${ }^{* *} P<0.01$; prepubertal (some estrogen stimulation) versus postpubertal (follicular).

metabolism of dimethylbenz(a)anthracene was highest in CL compared to preovulatory follicles. Furthermore, the higher concentrations of $\mathrm{BaP}$ metabolites in the $\mathrm{CL}$, particularly the metabolites in the organic fraction (less polar) could be secondary to the higher lipid content of the CL.

Benzo(a)pyrene metabolites, being lipid soluble are transported across the cell membrane by passive diffusion (Castelli et al., 2002), enter the germ cells and may cause apoptosis (Mattison et al., 1985) leading to ovarian follicular atresia (Hsueh et al., 1994; Mann et al., 1999; Savabieasfahani et al., 1999). Information on the composition of metabolites that arise from bioactivation of $\mathrm{BaP}$ in the presence of microsomes is relevant in understanding the causal factors involved in toxicity. Initial oxidation of BaP catalyzed by CYP450 family of enzymes (CYP1A1, CYP1A2, and CYP1B1) yield arene oxides (9-OH-BaP, 7-OH-BaP, 6-OH-BaP, 3-OH-BaP, and 1-OH-BaP). These arene oxides rearrange to phenols or undergo hydration catalyzed by epoxide hydrolase (EH) generating BaP-9,10-diol; BaP7,8-diol; and BaP-4,5-diol (reviewed in Ramesh et al., 2004; Shimada and Guengerich, 2006). Of the drug metabolizing enzymes that contribute to differential susceptibilities to the toxic effects of $\mathrm{BaP}$, the CYP1A1 is not constitutively expressed in various species and CYP1A2 is mostly hepatic (Guengerich, 1997). Therefore, the biotransformation of $\mathrm{BaP}$ by ovarian microsomes could have been the result of CYP1B1 and EH that were reported to be constitutively expressed in ovarian tissues (DiBiasio et al., 1991; Otto et al., 1992). One of the products of BaP biotransformation, the BaP-7,8-diol is further oxidized to 7,8,9,10-tetrahydrobenzo(a)pyrene (BPDE). This diol epoxide reacts with cellular macromolecules and cause toxicity (Xue and Warshawsky, 2005).

The $\mathrm{BaP}$ metabolites identified from both ovary and liver tissues were $\mathrm{BaP}$ 9,10-diol, $\mathrm{BaP}$ 4,5-diol, $\mathrm{BaP}$ 7,8diol, 3-hydroxy and 9-hydroxy BaP. There were no remarkable differences between hepatic and ovarian microsomes in the $\mathrm{BaP}$ metabolite types formed. The rodent ovarian microsomes produced considerably higher proportion $(P<$ 0.05 ; treatment $\times$ species interaction) of $\mathrm{BaP} 4,5$-diol, and 7,8-diol than the other animal species in this study. However, hepatic microsomes from the latter animal groups converted a greater proportion than rodents $(P<0.05$; treatment $\times$ species interaction) of $\mathrm{BaP}$ to 3- and 9-hydroxy $\mathrm{BaP}$ that are considered to be a part of the detoxification pathway.

Using estrogen receptor binding assays $\mathrm{BaP} /$ metabolites were estrogen antagonists (Arcaro et al., 1999). Furthermore, in vivo studies conducted in our laboratory have revealed that sub acute exposure to $\mathrm{BaP}$ resulted in antiestrogenic activities (Archibong et al., 2002) that are driven by $\mathrm{BaP}$ metabolism. Interestingly, the microsomal CYP families of enzymes that generate these metabolites in liver and extra hepatic tissues such as the ovary are also involved in steroid hormone metabolism (Jefcoate et al., 2000). Upon prolonged exposure to $\mathrm{BaP}$, sequestration of this chemical in high-density lipoproteins (Polyakov et al., 1996) that are essential for steroid hormone biosynthesis in the ovary cannot be ruled out. This can lead to reduced secretion of gonadotropins such as follicle-stimulating hormone (FSH) and luteinizing hormone ( $\mathrm{LH})$ at proestrus in lower mammalian species and at ovulatory phase of the menstrual cycle of women with adverse outcomes in the final stages of follicular development (Neal et al., 2007). Extrapolation of in vitro data to in vivo situation has some limitations in that, especially in farm animals, the likelihood of more amounts of biotransformation enzymes in one species and an intrinsically greater rate of clearance cannot be ruled out. Toward this end, our long-term goal is to study the biotransformation enzyme activities, expression and kinetic parameters, and the inhibition profiles for ovarian microsomes of each species and compare those obtained for human ovarian microsomes to assess the animal species most similar to humans who are exposed to PAHs via cigarette smoke, occupational settings, and diet.

Mention of trade names or commercial products is solely for the purpose of providing information and does not imply recommendation, endorsement, or exclusion of other suitable products by the U.S. Department of Agriculture. The contents of the 
publication are solely the responsibility of the authors and do not necessarily represent the official views of NIH or USDA or Meharry Medical College.

\section{REFERENCES}

Arcaro KF, O'Keefe PW, Yang Y, Clayton W, Gierthy JF. 1999. Antiestrogenicity of environmental polycyclic aromatic hydrocarbons in human breast cancer cells. Toxicology 133:115-127.

Archibong AE. 1987. Embryonic mortality in prepubertal gilts. PhD Thesis, Oregon State University, p 109.

Archibong AE, Inyang F, Ramesh A, Greenwood M, Nayyar T, Kopsombut P, Hood DB, Nyanda AM. 2002. Alteration of pregnancy related hormones and fetal survival in F-344 rats exposed by inhalation to benzo(a)pyrene. Reprod Toxicol 16:801-808.

Beach JB, Pellizzari E, Keever JT, Ellis L. 2000. Determination of benzo(a)pyrene and other polycyclic aromatic hydrocarbons (PAHs) at trace levels in human tissues. J Anal Toxicol 24:670677.

Bengtsson M, Dong Y, Mattison RD, Rydström J. 1987. Mechanisms of regulation of rat ovarian 7, 12-dimethylbenz(a)anthracene hydroxylase. Chem Biol Interact 63:15-27.

Borman SM, Christian PJ, Sipes IG, Hoyer PB. 2000. Ovotoxicity in female Fischer rats and B6 mice induced by low-dose exposure to three polycyclic aromatic hydrocarbons: Comparison through calculation of an ovotoxic index. Toxicol Appl Pharmacol 167:191-198.

Bradford M. 1976. A rapid and sensitive method for the quantification of microgram quantities of protein, utilizing the principle of dye binding. Anal Biochem 72:248-254.

Castelli F, Librando V, Sarpietro MG. 2002. Calorimetric approach of the interaction and absorption of polycyclic aromatic hydrocarbons with model membranes. Environ Sci Technol 36:2717-2723.

Charles GD, Bartels MJ, Zacharewski TR, Gollapudi BB, Freshour NL, Carney EW. 2000. Activity of benzo(a)pyrene and its hydroxylated metabolites in an estrogen receptor- $\alpha$ reporter gene assay. Toxicol Sci 55:320-326.

DiBiasio KW, Silva MH, Shull LR, Overstreet JW, Hammock BD, Miller MG. 1991. Xenobiotic metabolizing enzyme activities in rat, mouse, human and human ovary. Drug Metab Dispos 19:227-232.

Eliasson M, Brock S, Ahlberg MB. 1997. Evidence for mitochondrial metabolism of 7, 12-dimethylbenz(a)anthracene in porcine ovaries: Comparison with microsomal metabolism. Toxicology 122:11-21.

Goldman R, Enewold L, Pellizzari E, Beach JB, Bowman ED, Krishnan SS, Shields PG. 2001. Smoking increases carcinogenic polycyclic aromatic hydrocarbons in human lung tissue. Cancer Res 61:6367-6371.

Guengerich FP. 1997. Comparisons of catalytic activity of cytochrome P450 subfamily enzymes from different species. Chem Biol Interact 106:161-182.

Hsueh AJW, Billig H, Tsafriri A. 1994. Ovarian follicle atresia: A hormonally controlled apoptotic process. Endocr Rev 15:707724.
Inyang F, Ramesh A, Kopsombut P, Niaz MS, Hood DB, Nyanda AM, Archibong AE. 2003. Disruption of ovarian steroidogenesis and epididymal function by inhaled benzo(a)pyrene. Reprod Toxicol 17:527-537.

Ioannides C. 1999. Effect of diet and nutrition on the expression of cytochromes P450. Xenobiotica 29:109-154.

IPCS. 1998. Environmental Health Criteria 202: Selected non-heterocyclic polycyclic aromatic hydrocarbons. Lyon, France: International Programme on Chemical Safety, World Health Organization.

Jefcoate CR, Liehr JG, Santen RJ, Sutter TR, Yager JD, Yue W, Santner SJ, Tekmal R, Demers L, Pauley R, Naftolin F, Mor G, Berstein L. 2000. Tissue-specific synthesis and oxidative metabolism of estrogens. J Natl Cancer Inst Monogr 27:95-112.

Jurisicova A, Taniuchi A, Li H, Shang Y, Antenos M, Detmar J, Xu J, Matikainen T, Benito Hernández A, Numez G, Casper RF. 2007. Maternal exposure to polycyclic aromatic hydrocarbons diminishes murine ovarian reserve via induction of Harakiri. J Clin Invest 117:3971-3978.

Lewis DFV, Ioannides C, Parke DV. 1998. Cytochrome P450 and species differences in xenobiotic metabolism and activation of carcinogen. Environ Health Perspect 106:633-641.

Mann KK, Matulka RA, Hahn ME, Trombino AF, Lawrence BP, Kerkvliet NI, Sherr DH. 1999. The role of polycyclic aromatic hydrocarbon metabolism in dimethylbenz(a)anthracene-induced pre- $\beta$ lymphocyte apoptosis. Toxicol Appl Pharmacol 161:10-22.

Matikainen T, Perez GI, Jurisicova A, Pru JK, Schlezinger JJ, Ryu HY, Laine J, Sakai T, Korsmeyer SJ, Casper RF, Sherr DH, Tilly JL. 2001. Aromatic hydrocarbon receptor-driven Bax gene expression is required for premature ovarian failure caused by biohazardous environmental chemicals. Nat Genet 28:355-360.

Mattison DR, Shiromizu K, Nightingale MS. 1985. The role of metabolic activation in gonadal and gamete toxicity. In: Hemminki K, Sorsa M, Vainio H, editors. Occupational Hazards and Reproduction. New York: Hemisphere Publishing Company.

Neal MS, Zhu J, Holloway AC, Foster WG. 2007. Follicle growth is inhibited by benzo(a)pyrene, at concentrations representative of human exposure, in an isolated rat follicle culture assay. Hum Reprod 22:961-967.

NIH. 1981. Guidelines for the laboratory use of chemical carcinogens. NIH Publication No. 81-2385. Washington, DC: National Institutes of Health, US Government Printing Office.

Otto S, Bhattacharyya KK, Jefcoate CR. 1992. Polycyclic aromatic hydrocarbon metabolism in rat adrenal, ovary, and ovary microsomes is catalyzed by the same novel cytochrome P450 (P450RAP). Endocrinology 131:3067-3076.

Polyakov LM, Chasovskikh MI, Panin LE. 1996. Binding and treatment of benzo(a)pyrene by blood plasma lipoproteins: The possible role of apolipoprotein $\mathrm{B}$ in this process. Bioconjug Chem 7:396-400.

Ramesh A, Inyang F, Hood DB, Archibong AE, Knuckles ME, Nyanda AM. 2001. Metabolism, bioavailability, and toxicokinetics of benzo(a)pyrene in F344 rats following oral administration. Exp Toxicol Pathol 53:275-290.

Ramesh A, Inyang F, Lunstra DD, Niaz MS, Kopsombut P, Jones KM, Hood DB, Hills ER, Archibong AE. 2008. Alteration of fertility endpoints in adult male F-344 rats by sub-chronic exposure to inhaled benzo(a)pyrene. Exp Toxicol Pathol 60:269-280. 
Ramesh A, Walker SA, Hood DB, Guillén MD, Schneider K, Weyand EH. 2004. Bioavailability and risk assessment of orally ingested polycyclic aromatic hydrocarbons. Int $\mathrm{J}$ Toxicol 23:301-333.

Savabieasfahani M, Lochmiller RL, Janz DM. 1999. Elevated ovarian and thymic cell apoptosis in wild cotton rats inhabiting petrochemical-contaminated terrestrial ecosystems. J Toxicol Environ Health 57:521-527.

Schenkman JB, Jansson I. 1999. Measurement of cytochrome P450. In: Maines MD, Costa LG, Hodgson E, Reed DJ, Sipes IG, editors. Current Protocols in Toxicology. Hoboken, New Jersey: John Wiley. pp 4.1.1-4.1.14.

Shimada T, Guengerich FP. 2006. Inhibition of human cytochrome P450 1A1-, 1A2-, and 1B1-mediated activation of procarcinogens to genotoxic metabolites by polycyclic aromatic hydrocarbons. Chem Res Toxicol 19:288-294.

Steel RGD, Torrie JH. 1980. Principles and Procedures of Statistics: A Biometrical Approach. New York: McGraw-Hill. 512 p.

Tsai-Turton M, Nakamura BN, Luderer U. 2007. Induction of apoptosis by 9,10 -dimethyl-1,2-benzanthracene in cultured preovulatory rat follicles is preceded by a rise in reactive oxygen species and is prevented by glutathione. Biol Reprod 77:442-451.
Walker SA, Whitten LB, Seals GB, Lee WE, Archibong AE, Ramesh A. 2006. Inter-species comparison of liver and small intestinal microsomal metabolism of fluoranthene. Food Chem Toxicol 44:380-387.

Wall KL, Gao WS, te Koppele JM, Kwei GY, Kauffman FC, Thurman RG. 1991. The liver plays a central role in the mechanism of chemical carcinogenesis due to polycyclic aromatic hydrocarbons. Carcinogenesis 12:783786.

Walton K, Jean-Lou CM, Renwick AG. 2001. Default factors for interspecies differences in the major routes of xenobiotic elimination. Human Ecol Risk Assess 7:181-201.

WHO. 2001. Principles for evaluating health risks to reproduction associated with exposure to chemicals. Environmental Health Criteria 225. Geneva: World Health Organization. $141 \mathrm{p}$.

Xue W, Warshawsky D. 2005. Metabolic activation of polycyclic and heterocyclic aromatic hydrocarbons and DNA damage: A review. Toxicol Appl Pharmacol 206:73-93.

Younglai EV, Wu YJ, Foster WG. 2007. Reproductive toxicology of environmental toxicants: Emerging issues and concerns. Curr Pharm Des 13:3005-3019. 